\title{
Hydrogen peroxide as an alternate substrate for the oxygen-evolving complex
}

\author{
Wayne D. Frasch and Rui Mei \\ Division of Biological Sciences, The University of Michigan, Ann Arbor, MI (U.S.A.)
}

(Received 3 September 1986)

Key words: Photosystem II; Oxygen evolution; Hydrogen peroxide; Oxygen-evolving complex

Photosystem II reaction centers evolve $\mathrm{O}_{2}$ in the dark when $\mathrm{H}_{2} \mathrm{O}_{2}$ is added as a substrate. Although some of this activity can be attributed to catalase, as much as $75 \%$ of the activity was not affected by the addition of 1 mM KCN. Several lines of evidence demonstrate that this KCN-insensitive $\mathrm{O}_{2}$ evolution from $\mathrm{H}_{2} \mathrm{O}_{2}$ in the dark is catalyzed by the cycling of $\mathrm{S}$ states in the oxygen-evolving complex including: (1) inactivation of $\mathrm{H}_{2} \mathrm{O}_{2}$-mediated $\mathrm{O}_{2}$ evolution by Ca / EDTA washing; (2) susceptibility of the activity to inhibition by amines like ammonia and Tris; (3) inhibition by CCCP which is known to accelerate the rate of deactivation of the $\mathrm{S}_{2}$ state and; (4) a direct dependence of the rate of $\mathrm{O}_{2}$ evolution on the presence of calcium and (5) chloride.

\section{Introduction}

Photosynthetic oxygen evolution is catalyzed by the oxygen-evolving complex by cycling through five stable or semistable intermediate states known as $\mathrm{S}$ states $[1,2]$. By studying the interactions of flash-illuminated chloroplasts with hydrogen peroxide, Velthuys and Kok [3] found that $\mathrm{H}_{2} \mathrm{O}_{2}$ causes a two-electron donation to the oxygenevolving complex which reduces $S_{2}$ to $S_{0}$ and $S_{1}$ to $\mathrm{S}_{-1}$ in the dark. At the same time, $\mathrm{H}_{2} \mathrm{O}_{2}$ can cause a two-electron oxidation of the oxygen-evolving complex to regenerate $S_{2}$ and $S_{1}$ from $S_{0}$ and $S_{-1}$, respectively. Thus, it was proposed that the oxygen-evolving complex uses $\mathrm{H}_{2} \mathrm{O}_{2}$ in the dark as a substrate for catalase-like activity that utilizes a cycle between $S_{0}$ and $S_{2}$ or $S_{-1}$ and $S_{1}$. In this cycle, it was hypothesized that two molecules of

Abbreviations: Mes, 4-morpholineethanesulfonic acid; PS II, Photosystem II; CCCP, carbonyl cyanide $m$-chlorophenyl hydrazone.

Correspondence: W.D. Frasch, Division of Biological Sciences, The University of Michigan, Ann Arbor, MI 48109, U.S.A.
$\mathrm{H}_{2} \mathrm{O}_{2}$ dismute to form two water molecules and one molecule of oxygen.

The conversion of hydrogen peroxide to oxygen by Photosystem II has also been examined in the light [4-7]. Under these conditions, an electron acceptor on the reducing side of PS II is required. Free manganese was found to have an essential role in this light-dependent reaction, since the addition of EDTA abolished the effect [7]. The source of this free Mn may result from the release of $\mathrm{Mn}$ from the oxygen-evolving complex in the presence of $\mathrm{H}_{2} \mathrm{O}_{2}$ and light, since Sandusky and Yocum (personal communication) have found that addition of $\mathrm{H}_{2} \mathrm{O}_{2}$ in the light will cause the release of manganese in intact thylakoids. Ghanotakis et al. [9] found that the release of manganese and inactivation of photosynthetic $\mathrm{O}_{2}$ evolution from the oxygen-evolving complex caused by $\mathrm{H}_{2} \mathrm{O}_{2}$ and light was accelerated when the extrinsic 23 and 17 $\mathrm{kDa}$ proteins were removed.

Sayre and Homann [10] suggested that $\mathrm{H}_{2} \mathrm{O}_{2}$ may be produced by the oxygen-evolving complex upon illumination. The recent observation $[11,12]$ that inside-out thylakoids depleted of the 23 and $17 \mathrm{kDa}$ proteins produced significant amounts of 
$\mathrm{H}_{2} \mathrm{O}_{2}$ upon illumination supports and extends this hypothesis.

In thylakoids as well as PS II preparations, the rate of oxygen-evolving complex-catalyzed $\mathrm{O}_{2}$ evolution in the dark from $\mathrm{H}_{2} \mathrm{O}_{2}$ is barely detectable above the large background of $\mathrm{O}_{2}$ evolution catalyzed by the high abundance of catalase that is also present [3]. We have examined the evolution of $\mathrm{O}_{2}$ from $\mathrm{H}_{2} \mathrm{O}_{2}$ in the dark that is catalyzed by PS II reaction centers prepared as per Ghanotakis and Yocum [13]. We observed that the final step of purification of these reaction centers removes the majority of this catalase activity. The experiments described here indicate that in darkness, $\mathrm{H}_{2} \mathrm{O}_{2}$ is not inhibitory to the oxygen-evolving complex but that the cyanide-insensitive $\mathrm{O}_{2}$ evolution from $\mathrm{H}_{2} \mathrm{O}_{2}$ is catalyzed specifically by the oxygen-evolving complex of PS II.

\section{Methods and Materials}

Photosystem II preparations were isolated from spinach by a modification of the Bertold et al. [14] procedure as described by Bowlby and Frasch [15]. These PS II preparations were used to make PS II reaction centers as described by Ghanotakis and Yocum [13]. These reaction centers exhibited rates of $\mathrm{O}_{2}$ evolving activity of $1150-1285 \mu \mathrm{mol}$ $\mathrm{O}_{2} / \mathrm{mg} \mathrm{Chl}$ per $\mathrm{h}$.

Photosynthetic $\mathrm{O}_{2}$ evolution from PS II preparations was measured with a Clark-type electrode with $3 \mu \mathrm{g}$ of $\mathrm{Chl} / \mathrm{ml}$ in a $2 \mathrm{ml}$ reaction vessel, $250 \mu \mathrm{M}$ dichlorobenzoquinone and $3 \mathrm{mM}$ ferricyanide as an electron acceptor and $2 \mathrm{mM}$ sucrose, $50 \mathrm{mM}$ Mes (pH 6.0) and $10 \mathrm{mM} \mathrm{NaCl}$. Photosynthetic $\mathrm{O}_{2}$ evolution from PS II reaction centers was measured as described above but with the substitution of $10 \mathrm{mM} \mathrm{CaCl}$ for $\mathrm{NaCl}$. Oxygen evolution from $\mathrm{H}_{2} \mathrm{O}_{2}$ in darkness was measured in $50 \mathrm{mM}$ Mes (pH 6.0), $10 \mathrm{mM} \mathrm{CaCl}_{2}$, $50 \mu \mathrm{M} \mathrm{KCN}, 2 \mathrm{mM}$ sucrose and $80 \mathrm{mM} \mathrm{H} \mathrm{O}_{2}$ except where otherwise indicated. The reaction was started by the addition of $1.5 \mu \mathrm{g}$ of $\mathrm{Chl} / \mathrm{ml}$ of PS II reaction centers.

Removal of the manganese from the oxygenevolving complex by $\mathrm{Ca}$ (II)/EDTA-washing was done at $4^{\circ} \mathrm{C}$ by incubating reaction centers $(100$ $\mu \mathrm{g} \mathrm{Chl} / \mathrm{ml}$ ) for $1 \mathrm{~h}$ in $1 \mathrm{M} \mathrm{CaCl}_{2}$, before pelleting the membranes in a microfuge, resuspending the pellet in $50 \mathrm{mM} \mathrm{Mes}(\mathrm{pH} \mathrm{6)}$ to wash the membranes, then pelleting as before and resuspending in $50 \mathrm{mM}$ Mes ( $\mathrm{pH} \mathrm{6}$ ) with $20 \mathrm{mM}$ EDTA. After a $15 \mathrm{~min}$ incubation, the EDTA solution was removed by centrifugation as before. The membranes were washed once in Mes ( $\mathrm{pH} 6)$ before final resuspension in the same buffer.

The concentrations of free $\mathrm{Ca}(\mathrm{II})$ and free $\mathrm{Mn}$ (II) in the presence of EDTA was calculated by successive approximation using the stability constants for CaEDTA and MnEDTA from Martell and Smith [16].

\section{Results}

\section{Cyanide insensitivity}

Even highly purified PS II preparations contain substantial amounts of catalase. In the presence of $400 \mathrm{mM} \mathrm{H} \mathrm{O}_{2}$, the rate of $\mathrm{O}_{2}$ evolution in darkness was $17 \mathrm{mmol} \mathrm{O}_{2} / \mathrm{mg} \mathrm{Chl}$ per h. Since catalase is inhibited by low concentrations of cyanide, the fraction of $\mathrm{O}_{2}$ evolution that is attributable to catalase can be determined. Fig. 1 shows the effect of $\mathrm{KCN}$ on the rate of $\mathrm{O}_{2}$ evolution catalyzed by Photosystem II preparations using $\mathrm{H}_{2} \mathrm{O}_{2}$ in darkness. The vast majority of the activity catalyzed by PS II preparations was inhibited by low con-

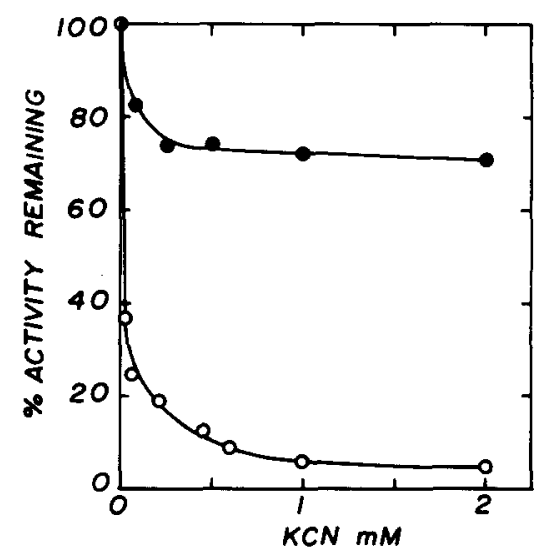

Fig. 1. Inhibition by $\mathrm{KCN}$ of $\mathrm{O}_{2}$ evolution in darkness with $\mathrm{H}_{2} \mathrm{O}_{2}$ as substrate catalyzed by Photosystem II preparations (O) or by PS II reaction center preparations $(\bullet)$. The membranes were prepared and rates of $\mathrm{O}_{2}$ evolution were assayed as described in Methods and Materials. The hydrogen peroxide concentration during the assay was $400 \mathrm{mM}$. The rates of $\mathrm{O}_{2}$ evolution in the dark in the absence of inhibitor were 17031 and $545 \mu \mathrm{mol} \mathrm{O}_{2} / \mathrm{mg} \mathrm{Chl}$ per h for the PS II preparations and PS II reaction center preparations, respectively. 
centrations of $\mathrm{KCN}$. With more than $95 \%$ of the observable $\mathrm{O}_{2}$ evolution resulting from catalase, it was impossible to measure accurately the rate which may have resulted specifically from the oxygen-evolving complex. However, purification of the PS II reaction centers from this PS II preparation yields membranes that are relative free of cyanide sensitive $\mathrm{O}_{2}$ evolution. In reaction centers where the rate of photosynthetic $\mathrm{O}_{2}$ evolution is $1280 \mu \mathrm{mol} \mathrm{O} / 2 \mathrm{mg} \mathrm{Chl} \mathrm{per} \mathrm{h,} \mathrm{a} \mathrm{rate} \mathrm{of} 545$ $\mu \mathrm{mol} \mathrm{O}_{2} / \mathrm{mg} \mathrm{Chl}$ per $\mathrm{h}$ could be observed in the dark upon addition of $\mathrm{H}_{2} \mathrm{O}_{2}$. As shown in Fig. 1, $75 \%$ of this rate was insensitive to $1 \mathrm{mM} \mathrm{KCN}$.

The cyanide-insensitive $\mathrm{O}_{2}$ evolution from $\mathrm{H}_{2} \mathrm{O}_{2}$ was examined to determine whether it originated from the oxygen-evolving complex. Washing membranes in $1 \mathrm{M} \mathrm{CaCl}_{2}$ removes the $33 \mathrm{kDa}$ protein and destabilizes the manganese of the oxygen-evolving complex such that the $\mathrm{Mn}$ is gradually released form the membrane [17]. Loss of the $\mathrm{Mn}$ in this manner results in irreversible inactivation of photosynthetic $\mathrm{O}_{2}$-evolving activity. Table I shows the effect of the Ca/EDTA washes and the effect of $\mathrm{KCN}$ on the rate of photosynthetic $\mathrm{O}_{2}$ evolution and $\mathrm{O}_{2}$ evolution in the dark with $\mathrm{H}_{2} \mathrm{O}_{2}$ as substrate catalyzed by reaction centers. The $\mathrm{Ca} / \mathrm{EDTA}$ washes abolished photosynthetic $\mathrm{O}_{2}$-evolving activity and decreased the dark $\mathrm{H}_{2} \mathrm{O}_{2}$-dependent activity to $35 \%$ of the control. The addition of $50 \mu \mathrm{M} \mathrm{KCN}$ to the reaction centers reduced the rate of $\mathrm{H}_{2} \mathrm{O}_{2}$-dependent $\mathrm{O}_{2}$ evolution by about $40 \%$, which is approximately the proportion of $\mathrm{Ca} / \mathrm{EDTA}$ insensitive activity. In fact, the addition of $50 \mu \mathrm{M} \mathrm{KCN}$ to $\mathrm{Ca} / \mathrm{EDTA}$-washed membranes was sufficient to inhibit all of the $\mathrm{O}_{2}$-evolving activity that re- mained. Similar results were obtained when the membranes were illuminated in $0.8 \mathrm{M}$ Tris $(\mathrm{pH}$ 8.4) and washed with $20 \mathrm{mM}$ EDTA to remove manganese from the oxygen-evolving complex (data not shown).

\section{Involvement of the $S_{2}$ state}

Several reagents will affect the $S_{2}$ state during photosynthetic $\mathrm{O}_{2}$ evolution. If the dark-catalyzed $\mathrm{O}_{2}$ evolution from $\mathrm{H}_{2} \mathrm{O}_{2}$ occurs via the two S-state cycles as hypothesized by Velthuys and Kok [3], the $S_{2}-S_{0}$ cycle should be affected by these reagents. Fig. 2 shows the effect Tris on the $\mathrm{O}_{2}$ evolution from $\mathrm{H}_{2} \mathrm{O}_{2}$ in darkness. $\mathrm{Up}$ to about $40 \%$ of the activity was inhibited by the presence of this amine during the reaction. Ammonium sulfate and $\mathrm{NH}_{4} \mathrm{Cl}$ caused inhibition of the dark $\mathrm{O}_{2}$ evolution in a similar manner (Fig. 3). The concentration dependence of these amines was approximately the same as observed previously for photosynthetic $\mathrm{O}_{2}$ evolution $[18,19]$. The anion associated with this inhibitor also had a significant effect on the concentration dependence but not the maximal extent of inhibition induced by ammonia. Lower concentrations of the amine were required to achieve maximal inhibition when sulfate was the counter ion than when chloride was used. The antagonistic effect between ammonia and chloride for inhibition of dark $\mathrm{O}_{2}$ evolution supports the involvement of the $\mathrm{S}_{2}$ state in this process, since it has been hypothesized that unprotonated ammonia inhibits photosynthetic $\mathrm{O}_{2}$ evolution by displacing the chloride that is required by the oxygen-evolving complex to progress beyond the $S_{2}$ state [20-23].

The dependence on $\mathrm{Cl}^{-}$of the rate of dark $\mathrm{O}_{2}$

\section{TABLE I}

THE EFFECT OF INACTIVATION OF PHOTOSYNTHETIC $\mathrm{O}_{2}$ EVOLUTION BY RELEASE OF MANGANESE ON THE RATE $(v)$ OF $\mathrm{O}_{2}$ EVOLUTION FROM $\mathrm{H}_{2} \mathrm{O}_{2}$ IN DARKNESS

Rates are expressed as $\mu \mathrm{mol} \mathrm{O}_{2} / \mathrm{mg} \mathrm{Chl}$ per $\mathrm{h}$.

\begin{tabular}{|c|c|c|c|c|c|c|}
\hline \multirow{3}{*}{ Treatment } & \multirow{2}{*}{\multicolumn{2}{|c|}{$\mathrm{H}_{2} \mathrm{O} \stackrel{h \nu}{\rightarrow} \mathrm{O}_{2}$}} & \multirow{2}{*}{\multicolumn{2}{|c|}{$\mathrm{H}_{2} \mathrm{O}_{2} \rightarrow \mathrm{O}_{2}$}} & \multicolumn{2}{|c|}{$+50 \mu \mathrm{M} \mathrm{KCN}$} \\
\hline & & & & & $\mathrm{H}_{2} \mathrm{O}$ & $\mathrm{O}_{2}$ \\
\hline & $v$ & $\%$ & $v$ & $\%$ & $v$ & $\%$ \\
\hline Control & 1250 & 100 & 563 & 100 & 333 & 100 \\
\hline $\mathrm{CaCl}_{2} /$ EDTA-washed & 0 & 0 & 195 & 35 & 0 & 0 \\
\hline
\end{tabular}

\footnotetext{
a Photosynthetic $\mathrm{O}_{2}$ evolution as described in Methods and Materials.
} 


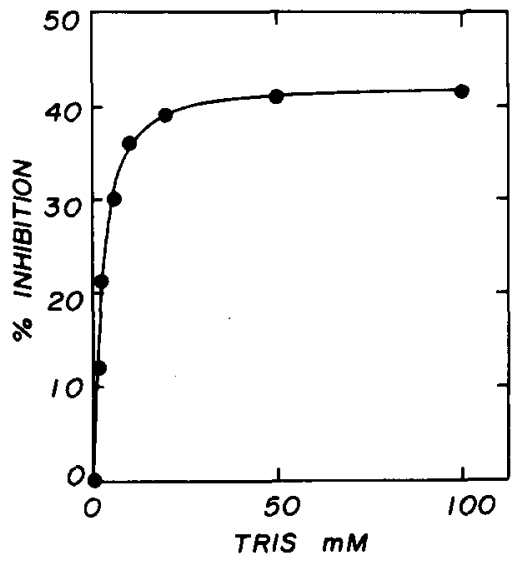

Fig. 2. Inhibition by Tris of $\mathrm{O}_{2}$ evolution in darkness with $\mathrm{H}_{2} \mathrm{O}_{2}$ as substrate catalyzed by PS II reaction center preparations. The concentrations of Tris indicated were added directly to the assay vessel in darkness. The rate of $\mathrm{O}_{2}$ evolution from $\mathrm{H}_{2} \mathrm{O}_{2}$ in the absence of Tris was $333 \mu \mathrm{mol} \mathrm{O} / 2 / \mathrm{mg} \mathrm{Chl} \mathrm{per} \mathrm{h.}$

evolution from $\mathrm{H}_{2} \mathrm{O}_{2}$ was examined directly in Fig. 4. Depletion of the chloride from these reaction centers by dialysis was sufficient to eliminate all of the photosynthetic $\mathrm{O}_{2}$ evolving activity in a reversible manner. However, the chloride-depleted membranes were still capable of evolving significant amounts of $\mathrm{O}_{2}$ from $\mathrm{H}_{2} \mathrm{O}_{2}$ in the dark. This latter rate of $\mathrm{O}_{2}$ evolution was dependent on the

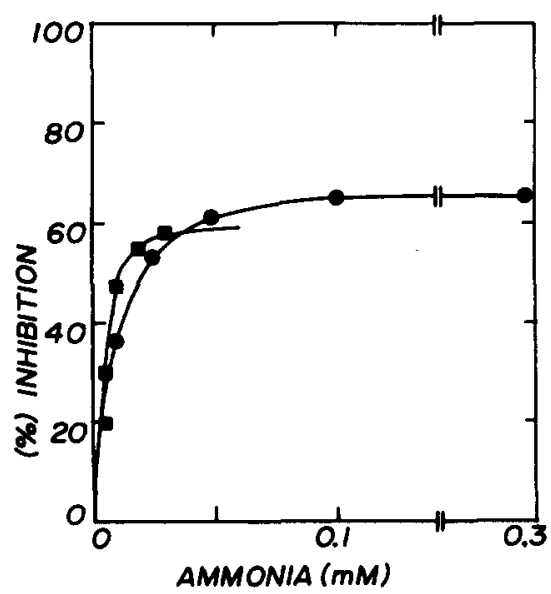

Fig. 3. Inhibition by ammonia of $\mathrm{O}_{2}$ evolution in darkness with $\mathrm{H}_{2} \mathrm{O}_{2}$ as substrate catalyzed by PS II reaction center preparations. Ammonia was added to the reaction vessel as either ammonium sulfate ( $(\square)$ or as ammonium chloride (๑) and is expressed as the total concentration of the protonated and unprotonated amine species. The rates of $\mathrm{O}_{2}$ evolution in the absence of inhibitor were $593 \mu \mathrm{mol} \mathrm{O} / 2 / \mathrm{mg} \mathrm{Chl} \mathrm{per} \mathrm{h.}$

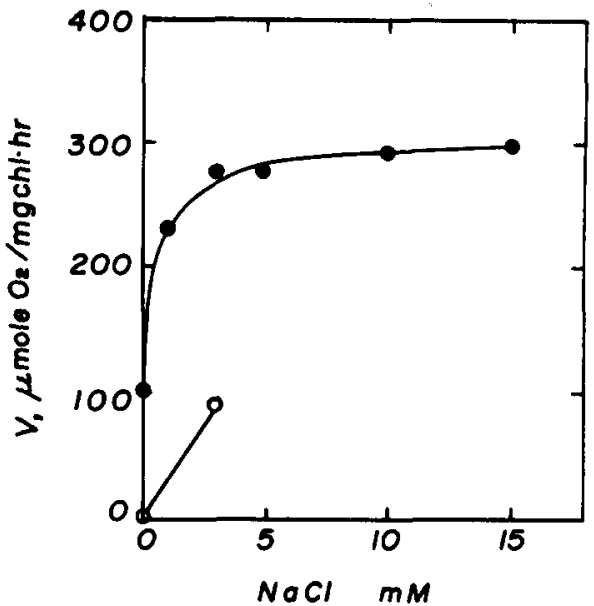

Fig. 4. Activation by chloride of the rate of $\mathrm{O}_{2}$ evolution in darkness with $\mathrm{H}_{2} \mathrm{O}_{2}$ as substrate catalyzed by PS II reaction center preparations. The reaction center membranes were depleted of $\mathrm{Cl}^{-}$by washing in Mes ( $\mathrm{pH}$ 6), then dialysing the membranes in the same buffer for $3 \mathrm{~h}$ at $4^{\circ} \mathrm{C}$. The rate of photosynthetic $\mathrm{O}_{2}$ evolution prior to $\mathrm{Cl}^{-}$depletion was 930 $\mu \mathrm{mol} \mathrm{O}_{2} / \mathrm{mg} \mathrm{Chl}$ per $\mathrm{h}$ and after depletion was as indicated by the open circles. The rate of $\mathrm{O}_{2}$ evolution from $\mathrm{H}_{2} \mathrm{O}_{2}$ in darkness after depletion of chloride is indicated by the closed circles.

presence of $\mathrm{Cl}^{-}$and was found to increase up to about 2-fold upon addition of the anion. The concentration dependence for the enhancement of the rate by $\mathrm{Cl}^{-}$was similar to that observed for photosynthetic $\mathrm{O}_{2}$ evolution [13]. Fluoride, known to compete with the binding of $\mathrm{Cl}^{-}$in the oxygen-evolving complex and inhibit photosynthetic $\mathrm{O}_{2}$ evolving activity [23], also inhibits $\mathrm{O}_{2}$ evolution from $\mathrm{H}_{2} \mathrm{O}_{2}$ in darkness, as shown in Fig. 5. As with other inhibitors specific to the $S_{2}$ state, $\mathrm{F}^{-}$effectively removed only about half of this activity in darkness.

The rate of deactivation of the $S_{2}$ state is greatly accelerated by reagents like CCCP [24]. The effect of CCCP on the rate of $\mathrm{O}_{2}$ evolution from $\mathrm{H}_{2} \mathrm{O}_{2}$ is shown in Fig. 6. Concentrations of CCCP comparable to those known to accelerate deactivation of the $\mathrm{S}_{2}$ states were found to inhibit this $\mathrm{O}_{2}$ evolution in darkness. However, concentrations higher than $1 \mu \mathrm{M} \mathrm{CCCP}$ did not decrease the activity below $50 \%$ of the control.

\section{The role of divalent cations}

The reaction-center preparation used for these assays is lacking the $23 \mathrm{kDa}$ protein. Under such 


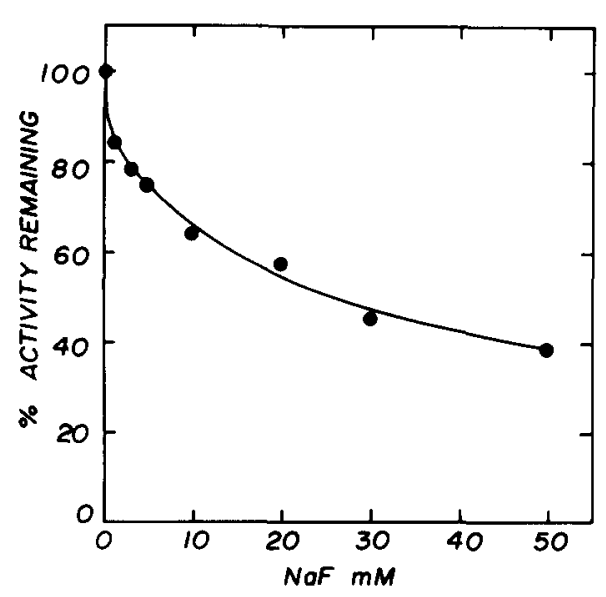

Fig. 5. Inhibition by fluoride of the rate of $\mathrm{O}_{2}$ evolution catalyzed by PS II reaction centers in darkness with $\mathrm{H}_{2} \mathrm{O}_{2}$ as substrate. The rate of $\mathrm{O}_{2}$ evolution was $491 \mu \mathrm{mol} \mathrm{O} \mathrm{O}_{2} / \mathrm{mg} \mathrm{Chl}$ per $h$ in the absence of inhibitor.

conditions, rates of photosynthetic $\mathrm{O}_{2}$ evolution are about one-third of the rate that can be achieved if $5 \mathrm{mM} \mathrm{Ca}$ (II) is added [13]. The partial dependence on $\mathrm{Ca}(\mathrm{II})$ of the rate of $\mathrm{O}_{2}$ evolution from $\mathrm{H}_{2} \mathrm{O}_{2}$ in the dark is confirmed by the experiment shown in Fig. 7. In the absence of $\mathrm{Ca}$ (II), a rate of $520 \mu \mathrm{mol} \mathrm{O} \mathrm{O}_{2} / \mathrm{mg} \mathrm{Chl} \mathrm{per} \mathrm{h}$ was observed. This rate increased more than 2 -fold upon addition of the divalent cation until a maximal rate was observed at $5 \mathrm{mM} \mathrm{Ca(II).} \mathrm{These} \mathrm{results} \mathrm{are} \mathrm{com-}$ parable to the dependence of photosynthetic $\mathrm{O}_{2}$

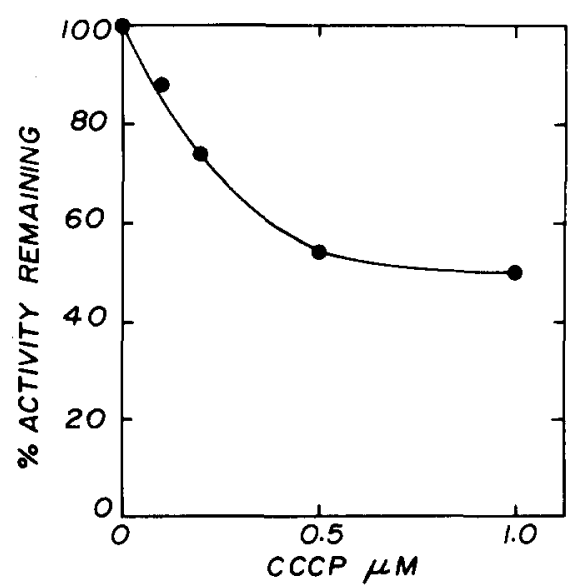

Fig. 6. Inhibition by $\mathrm{CCCP}$ of the rate of $\mathrm{O}_{2}$ evolution catalyzed by PS II reaction centers in darkness with $\mathrm{H}_{2} \mathrm{O}_{2}$ as substrate. The rate of $\mathrm{O}_{2}$ evolution in the absence of CCCP was $186 \mu \mathrm{mol} \mathrm{O}_{2} / \mathrm{mg} \mathrm{Chl} \mathrm{per} \mathrm{h.}$ evolution on $\mathrm{Ca}(\mathrm{II})$ in terms of the fraction of residual activity, extent of enhancement of activity and the concentration dependence on $\mathrm{Ca}$ (II).

The effect of the rate of $\mathrm{O}_{2}$ from $\mathrm{H}_{2} \mathrm{O}_{2}$ in darkness on the concentration of divalent cations was also determined by the addition of EDTA. The manganese concentration in the assay that is associated with the oxygen-evolving complex was estimated to be $0.15 \mu \mathrm{M}$. Assuming all of this $\mathrm{Mn}$ was accessible to EDTA, the concentration of free $\mathrm{Mn}(\mathrm{II})$ and $\mathrm{Ca}(\mathrm{II})$ in the presence of EDTA was determined by iteration using the stability constants for the EDTA complexes of these cations [16]. Because the stability constant of MnEDTA is three orders of magnitude tighter than that of CaEDTA, addition of $0.1 \mathrm{mM}$ EDTA was enough to completely remove the manganese from the solution in the presence of $5 \mathrm{mM}$ calcium, even if all $0.15 \mu \mathrm{M} \mathrm{Mn}$ in the sample were solvent-accessible. However, as denoted by the squares in Fig. 7 , addition of the EDTA affected the rate of $\mathrm{O}_{2}$ evolution from $\mathrm{H}_{2} \mathrm{O}_{2}$ in the dark in a manner similar to the depletion of $\mathrm{Ca}(\mathrm{II})$ alone. This suggests that $\mathrm{H}_{2} \mathrm{O}_{2}$ does not cause the release of $\mathrm{Mn}$ from the oxygen-evolving complex in the dark. These conclusions are supported further by the observation that addition of $\mathrm{Mn}(\mathrm{II})$ to the assay does not facilitate the rate of $\mathrm{O}_{2}$ evolution from

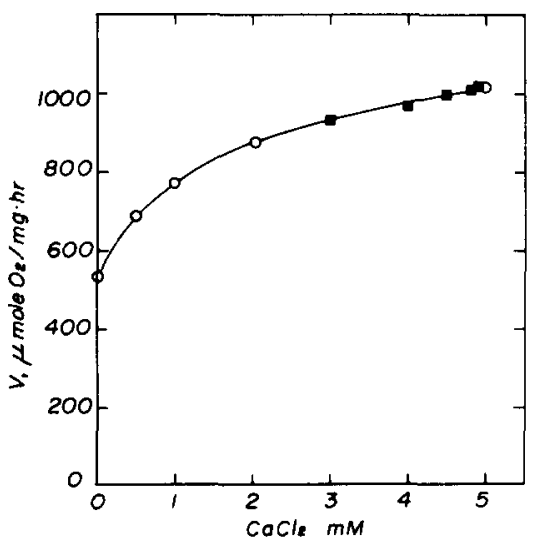

Fig. 7. The dependence on calcium of the rate of $\mathrm{O}_{2}$ evolution catalyzed by PS II reaction centers in darkness with $\mathrm{H}_{2} \mathrm{O}_{2}$ as substrate. The rates are plotted as a function of the addition of $\mathrm{CaCl}_{2}$ to the assay (O) and as a function of the depletion of $\mathrm{Ca}$ (II) from the assay by the addition of EDTA in the presence of $5 \mathrm{mM} \mathrm{Ca}$ (II) (E). The concentration of free $\mathrm{Ca}$ (II) after the addition of EDTA was determined as described in Methods and Materials. 
TABLE II

THE EFFECT OF FREE MANGANESE ON THE RATE OF $\mathrm{O}_{2}$ EVOLUTION IN DARKNESS FROM $\mathrm{H}_{2} \mathrm{O}_{2}$

\begin{tabular}{llll}
\hline $\begin{array}{l}\mathrm{Ca}(\mathrm{II}) \\
(\mathrm{mM})\end{array}$ & $\begin{array}{l}\mathrm{Mn}(\mathrm{II}) \\
(\mathrm{mM})\end{array}$ & $\begin{array}{l}\text { EDTA } \\
(\mathrm{mM})\end{array}$ & $\begin{array}{l}v(\mu \mathrm{mol} \mathrm{O} / \\
\mathrm{mg} \mathrm{Chl} \mathrm{per} \mathrm{h})\end{array}$ \\
\hline 5 & 0 & 0 & 758 \\
5 & 0 & 0.1 & 720 \\
5 & 0.11 & 0.1 & 657 \\
5 & 0.20 & 0.1 & 558 \\
\hline
\end{tabular}

$\mathrm{H}_{2} \mathrm{O}_{2}$ in darkness (Table II), but inhibits it. The cause of this inhibition is unclear but may result from competition for the binding of $\mathrm{Ca}$ (II).

\section{Discussion}

The results described above demonstrated that the $\mathrm{O}_{2}$ evolved in darkness from reaction centers when $\mathrm{H}_{2} \mathrm{O}_{2}$ is used as a substrate is catalyzed by the oxygen-evolving complex. This evidence includes: (i) cyanide insensitivity, which shows that the activity does not originate from catalase; (ii) inactivation by $\mathrm{Ca}$ (II)/EDTA washing or by Tris-washing; (iii) inhibition by Tris, ammonia, fluoride or CCCP; (iv) a direct dependence of the rate on calcium and (v) on chloride.

Velthuys and Kok [3] proposed a model for the conversion of $\mathrm{H}_{2} \mathrm{O}_{2}$ to $\mathrm{O}_{2}$ catalyzed by the oxygen-evolving complex. In this model, the $\mathrm{S}_{0}$ state can be oxidized to $\mathrm{S}_{2}$ by $\mathrm{H}_{2} \mathrm{O}_{2}$ to yield water. The $\mathrm{S}_{2}$ state can then catalyze the oxidation of $\mathrm{H}_{2} \mathrm{O}_{2}$ to $\mathrm{O}_{2}$ to return to the $\mathrm{S}_{0}$ state (Fig. 8A). From flash yield experiments, these workers hypothesized that a cycle that involves the $S_{1}$ and $\mathrm{S}_{-1}$ states could evolve $\mathrm{O}_{2}$ from $\mathrm{H}_{2} \mathrm{O}_{2}$ as well. Several of the experiments reported here support the hypothesis that both a cycle that involves $S_{2}$ and one independent of $\mathrm{S}_{2}$ operate to evolve $\mathrm{O}_{2}$ evolution from $\mathrm{H}_{2} \mathrm{O}_{2}$ in darkness. The reagents that are believed to inhibit $\mathrm{S}_{2}$ specifically, which include ammonia [18] Tris [19] and fluoride [23], inhibit this activity in the dark. The reagent CCCP, known to accelerate the rate of deactivation of the $S_{2}$ state [24] and keep the concentration of $S_{2}$ low, also is inhibitory. Several lines of evidence suggest that chloride is required for the formation of a competent $S_{2}$ state [20-23] and it has been sug- gested that the chloride is required as a bridging ligand between the manganese of the oxygenevolving complex [20]. As with the other $\mathrm{S}_{2}$-specific processes, depletion of chloride also inhibits $\mathrm{O}_{2}$ evolution from $\mathrm{H}_{2} \mathrm{O}_{2}$ in the dark. However, although all of these treatments affect this activity, none is able to decrease the rate of $\mathrm{O}_{2}$ evolution by more than $50 \%$, which suggests that the oxygen-evolving complex can evolve $\mathrm{O}_{2}$ via a cycle that does not involve $S_{2}$ as well.

The $\mathrm{S}_{2}-\mathrm{S}_{0}$ hydrogen peroxide cycle was believed to be more efficient than the $S_{1}-S_{-1}$ cycle [3]. The membranes used in the current study were dark adapted such that the ratio of $S_{1}$ to $S_{0}$ was approx. $75: 25$. Since the $S_{2}$-specific inhibitors induced up to $50 \%$ inhibition, the $\mathrm{S}_{2}-\mathrm{S}_{0}$ cycle must be responsible for a greater fraction of the activity when both cycles are free to evolve $\mathrm{O}_{2}$ from $\mathrm{H}_{2} \mathrm{O}_{2}$.

In previous studies where $\mathrm{H}_{2} \mathrm{O}_{2}$ is used as an alternate substrate for $\mathrm{O}_{2}$ evolution by PS II, the membranes have been illuminated [4-7]. This reaction has been found to depend on the presence of $\mathrm{Mn}$ (II) in solution and can be inhibited by low concentrations of EDTA [7]. In the present study, concentrations of EDTA that will remove all of the manganese free in solution during the assay did not affect the rate of $\mathrm{O}_{2}$ evolution from $\mathrm{H}_{2} \mathrm{O}_{2}$ in darkness as long as enough $\mathrm{Ca}(\mathrm{II})$ was available. This suggests that $\mathrm{H}_{2} \mathrm{O}_{2}$ in darkness does not cause the release of free $\mathrm{Mn}$ from the oxygenevolving complex and that $\mathrm{Mn}$ is not required for $\mathrm{O}_{2}$ evolution from $\mathrm{H}_{2} \mathrm{O}_{2}$. The dependence of light-mediated $\mathrm{O}_{2}$ evolution from $\mathrm{H}_{2} \mathrm{O}_{2}$ on manganese in solution suggests that this process may be mediated by the mechanism shown in Fig. 8B. In this mechanism, light causes the formation of higher $\mathrm{S}$ states. Hydrogen peroxide interacts with the higher $\mathbf{S}$ states to cause the release of $\mathrm{Mn}$ from the oxygen-evolving complex. The light then

$A$

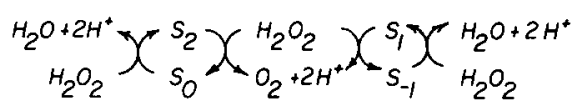

B.

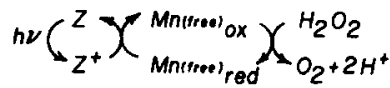

Fig. 8. Proposed mechanisms for $\mathrm{O}_{2}$ (A) evolution from $\mathrm{H}_{2} \mathrm{O}_{2}$ (A) in the dark after Velthuys and Kok [3], and (B) during illumination. 
generates the oxidant, $\mathrm{Z}^{+}$, which is capable of oxidizing $\mathrm{Mn}$ (II) in solution under conditions in which the oxygen-evolving complex is inhibited. The oxidized manganese catalyzes the oxidation of $\mathrm{H}_{2} \mathrm{O}_{2}$ to $\mathrm{O}_{2}$. In this reaction, $\mathrm{H}_{2} \mathrm{O}_{2}$ does not cause the interconversion of the $\mathrm{S}$ states of the oxygenevolving complex. This mechanism is supported by recent observations of Sandusky [25] and Yocum that show that $\mathrm{H}_{2} \mathrm{O}_{2}$ causes the release of $\mathrm{Mn}$ from the oxygen-evolving complex upon illumination. Since Velthuys and Kok [3] found that the addition of $\mathrm{H}_{2} \mathrm{O}_{2}$ upon formation of the $\mathrm{S}_{3}$ state was not inhibitory but promoted the $\mathrm{S}_{1}-\mathrm{S}_{-1}$ cycle, $\mathrm{H}_{2} \mathrm{O}_{2}$ may induce the release of $\mathrm{Mn}$ from the oxygen-evolving complex upon formation of the $\mathrm{S}_{4}$ state.

The results presented here show that $\mathrm{H}_{2} \mathrm{O}_{2}$ can cause the direct interconversion of the $\mathrm{S}$ states. This reaction provides an assay for the oxygenevolving complex which is independent of the photoreaction and allows the substrate concentration to be varied.

\section{Acknowledgements}

This study was supported by research grants from the National Science Foundation (DMB8604118), the Rackham Foundation, the Office of Energy Research and a National Institutes of Health Biomedical Research Support Grant to the Vice President for Research to W.D.F.

\section{References}

1 Kok, B., Forbush, B. and McGloin, M. (1970) Photochem. Photobiol. 11, 457-475

2 Forbush, B., Kok, B. and McGloin, M. (1971) Photochem. Photobiol. 14, 307-321
3 Velthuys, B. and Kok, B. (1978) Biochim. Biophys. Acta $502,211-221$

4 Inoue, H. and Nishimura, M. (1971) Plant Cell Physiol. 12, 739-747

5 Takahama, U., Inoue, H. and Nishimura, M. (1974) Plant Cell Physiol. 15, 971-978

6 Takahama, U., Inoue, H. and Nishimura, M. (1974) Plant Cell Physiol. 15, 979-986

7 Velthuys, B. (1983) in The Oxygen-Evolving System of Photosynthesis (Inoue, Y., Crofts, A.R., Govinjee, Murata, N., Renger, G. and Satoh, K., eds.), pp. 83-90, Academic Press, Tokyo

8 Reference deleted

9 Ghanotakis, D., Topper, J.N. and Yocum, C.F. (1984) Biochim. Biophys. Acta 767, 524-531

10 Sayre, R.T. and Homann, P.H. (1979) Arch. Biochem. Biophys. 1996, 525-533

11 Åkerlund, H.-E. (1984) in Advances in Photosynthesis Research (Sybesma, C., ed.), Vol. I, pp. 391-394, Martinus Nijhoff/Dr. W. Junk, Dordrecht

12 Schröder, W.P. and Åkerlund, H.-E. (1986) Biochim. Biophys. Acta $848,359-363$

13 Ghanotakis, D.F. and Yocum, C.F. (1986) FEBS Lett. 197, 244-248

14 Bertold, D.A., Babcock, G.T. and Yocum, C.F. (1981) FEBS Lett. 134, 231-234

15 Bowlby, N.R. and Frasch, W.D. (1986) Biochemistry 25, 1402-1407

16 Martell, A.E. and Smith, R.M. (1974) Critical Stability Constants, Vol. I, pp. 204-211, Plenum Press, New York

17 Ono, T. and Inoue, I. (1984) FEBS Lett. 168, 281-286

18 Velthuys, B. (1975) Biochim. Biophys. Acta 396, 392-401

19 Frasch, W.D. and Cheniae, G.M. (1980) Plant Physiol. 65, $735-745$

20 Sandusky, P.O. and Yocum, C.F. (1984) Biochim. Biophys. Acta $766,603-611$

21 Itoh, S., Yerkes, C.T., Koike, H., Robinson, H.H. and Crofts, A.R. (1984) Biochim. Biophys. Acta 766, 612-622

22 Theg, S., Jursinic, P. and Homan, P. (1984) Biochim. Biophys. Acta 766, 636-646

23 Sandusky, P.O. and Yocum, C.F. (1986) Biochim. Biophys. Acta $849,85-93$

24 Renger, G. (1972) Biochim. Biophys. Acta 256, 428-439

25 Sandusky, P.O. (1985) Ph.D. Dissertation, University of Michigan, Ann Arbor, MI 